DOI

\title{
ПРОАТЕРОГЕННІ МЕТАБОЛІЧНІ РОЗЛАДИ ТА ОЦІНКА СИСТЕМИ ПЕРОКСИДАЦІЇ ЛІПІДІВ У КУРЦІВ, ХВОРИХ НА НЕСТАБІЛЬНУ СТЕНОКАРДІЮ
}

\author{
๑Т. М. Соломенчук, А. О. Бедзай \\ Львівський національний медичний університет імені Данила Галицького
}

\begin{abstract}
РЕЗЮМЕ. Обстежено 68 хворих на нестабільну стенокардію (НС), з яких 23 жінки курці, 24 жінки, які не курили і не зазнавали пасивного впливу куріння та 21 чоловік-курець. У жінок-курців, порівняно з жінками, які не курили та чоловіками-курцями, спостерігалось зростання показників загального холестерину (ЗХС), холестерину ліпопротеїдів низької густини (ХС ЛПНГ), холестерину ліпопротеїдів дуже низької густини (ХС ЛПДНГ), тригліцеридів (ТГ) та активності ПОЛ, а вміст ХС ЛПВГ був нижчим, ніж у жінок-некурців та чоловіків-курців. Рівень церулоплазміну (ЦП) був вищим у чоловіків-курців, ніж у жінок-курців і некурців, в яких рівень ЦП був практично однаковий.
\end{abstract}

КлЮчОВІ СлОВА: нестабільна стенокардія, жінки-курці, жінки-некурці, чоловіки-курці, ліпідний обмін, перекисне окиснення ліпідів.

Вступ. Куріння $€$ другим за значенням після дисліпідемії (ДЛП) чинником розвитку гострого інфаркту міокарда (IM) та інших гострих форм IXC у людей молодого і середнього віку, незалежно від їх статі і професії, та, водночас, одним із найпоширеніших факторів ризику, який реєструється у понад $72 \%$ випадків [1]. Ймовірність захворіти прямо пропорційна інтенсивності куріння і залежить як від кількості викурюваних щодня сигарет, так і від загального стажу куріння.

Особливо небезпечним для кардіоваскулярного здоров'я $\epsilon$ куріння у жінок $[2,3]$. Його поширеність у цій гендерній групі в Україні за останні 30 років потроїлась, що пов'язують і зі зростанням серед жінок частоти розвитку IXC та її гострих форм, зокрема, нестабільної стенокардії [4-7].

Куріння сприяє появі або посиленню дії інших важливих факторів високого серцево-судинного ризику, зокрема, атерогенної ДЛП. У класичних популяційних дослідженнях (MRFIT [Multiple Risk Factor Intervention Trial], LRC [Lipid Research Clinics]) доведено наявність прямого зв'язку між рівнем у плазмі крові 3ХС i/або ХС ЛПнГ та поширеністю IXC як серед жінок, так і серед чоловіків. За даними C. N. Hennekens, на відміну від некурців, у жінок-курців реєструють більш агресивний проатерогенний ліпідний обмін та у 6 разів вищий ризик розвитку IXC [8]. Довготривале куріння призводить до розладу коронарного та мозкового кровотоку, що може бути пов'язане з ураженням структури і функції за рахунок як прямого його пошкодження ксенобіотиками, які містяться в сигаретному диму так і з проатерогенною модифікацією ліпідного обміну $[9,10]$.

Карбон (II) оксид сигаретного диму спричиняє окисну модифікацію ліпідів, підвищує синтез холестерину, знижує активність ендотеліальної ліпопротеїнліпази та лецитин-холестерил-ацилтрансферази. Усе це призводить до інтенсифі- кації проатерогенних порушень метаболізму і транспорту ліпідів, збільшення адгезії та агрегації тромбоцитів, розвитку цитотоксичного ефекту щодо ендотелію артерій. У більшості курців спостерігається гіперхолестеринемія, а у деяких домінує підвищення рівня ТГ, що вважається ще більш чутливим предиктором СС-ризику, асоційованим з курінням. Перекисно-модифіковані внаслідок дії сигаретного диму фракції ХС ЛПНГ, набуваючи найвищого проатерогенного потенціалу, спричиняють пряму ендотеліотоксичну дію та запускають процеси атерогенезу [3].

Дані епідеміологічних досліджень вказують, що навіть при дуже малій інтенсивності впливу, що відповідає пасивному курінню або вживанню 1-2 сигарет на день, ризик IXC різко зростає і відносний ії ризик досягає значення 1,3. У подальшому, при інтенсивності куріння більше 5 сигарет, середнє значення відносного ризику у активних курців становить 1,5, а при 20 сигаретах в день 1,8 [11]. Важливо зауважити, що вже при невисокій інтенсивності куріння ризик гострих форм IXC зростає швидко і нелінійно. При більшій інтенсивності ризик високий, але не відбувається його суттєвого зростання з подальшим збільшенням інтенсивності куріння [12].

Не дивлячись на численність наукових робіт, які присвячені вивченню процесів ліпідного обміну і пОЛ при ССЗ, залишаються невирішеними питання, в якій мірі куріння впливає на показники ліпідного спектра крові і пОЛ у жінок-курців і некурців та у чоловіків-курців, хворих на НС.

Мета дослідження. Вивчити гендерні особливості ліпідного обміну і стану системи ПОЛ у хворих на НС залежно від звички куріння.

Матеріал і методи дослідження. Обстежено 68 хворих, госпіталізованих з приводу НС. Залежно від звички куріння всіх пацієнтів поділили на три групи. I групу склали 23 жінки-курці (серед- 
Огляди літератури, оригінальні дослідження, погляд на проблему

ній вік $(44,31 \pm 0,27)$ років), II групу - 24 жінки, які не курили і не зазнавали пасивного впливу куріння (середній вік - $(51,82 \pm 0,31)$ років), III групу 21 чоловік-курець (середній вік $(43,36 \pm 0,46)$ років). Наявність куріння в анамнезі життя пацієнтів уточнювали за допомогою стандартного уніфікованого опитувальника, запропонованого експертами ВООЗ [13]. Жінки-курці та чоловіки-курці мали середній стаж куріння $(17,83 \pm 0,57)$ років та в переважній більшості $(84,6 \% \pm 0,59)$ викурювали понад 10 сигарет на добу.

Для оцінки стану ліпідного обміну визначали рівні основних показників ліпідного обміну загального холестерину, холестерину ліпопротеїдів низької густини, холестерину ліпопротеїдів дуже низької густини, холестерину ліпопротеїдів високої густини і тригліцеридів. Концентрації ЗХС і ТГ у сироватці крові визначали ферментативним методом за Rifai N. et al. (1999). Вміст ХC лПНГ розраховували за формулою Фрідвальда
(ХСЛПНГ=3ХС-(ХСЛПВГ+ТГ/2,2)) (ммоль/л). Стан ПОЛ оцінювали за вмістом малонового діальдегіду (МДА) (методом В. Б. Гаврилова в модифікації Е. Н. Коробейнікової (1989)) та активністю церулоплазміну (ЦП) (методом Н. Ревіна в модифікації С. В. Бестужева і В. Г. Колб (1982)). Отримані в результаті досліджень цифрові дані оброблено на персональному комп'ютері за допомогою прикладних програм «Microsoft Office Excel 2013».

Результати й обговорення. У курців визначають низький рівень ХС ЛПВГ, а також співвідношення ХС ЛПНГ / ХС ЛПВГ на користь збільшення частини атерогенних фракцій ліпопротеїдів $[9,10,14]$.

Результати наших досліджень (табл. 1) свідчать, що через куріння у жінок-курців достовірно підвищується сироватковий вміст $3 X \mathrm{X}(\mathrm{p}<0,05)$ переважно за рахунок ХС ЛПНГ ( $<<0,05)$, знижується рівень ХС ЛПВГ $(p<0,01)$ порівняно з хворими на НС жінками, які ніколи не курили.

Таблиця 1. Основні показники ліпідного обміну у хворих на нестабільну стенокардію залежно від статі і звички куріння

\begin{tabular}{|c|c|c|c|}
\hline Показники & $\begin{array}{c}\text { I група } \\
(\mathrm{n}=23)\end{array}$ & $\begin{array}{c}\text { II група } \\
(\mathrm{n}=24)\end{array}$ & $\begin{array}{c}\text { III група } \\
(\mathrm{n}=21)\end{array}$ \\
\hline ЗХС, ммоль/л & $6,86 \pm 0,34 \# \# \#$ & $5,67 \pm 0,29 *^{\circ} \# \# \#$ & $5,47 \pm 0,25^{\circ} \# \# \#$ \\
\hline ХС лПНГ, ммоль/л & $4,39 \pm 0,27 \# \#$ & $3,46 \pm 0,38^{\circ} \# \# \#$ & $3,39 \pm 0,16^{\circ} \# \# \#$ \\
\hline ХС лПДНГ, ммоль/л & $1,14 \pm 0,19 \# \#$ & $0,94 \pm 0,16^{\circ} \# \# \#$ & $0,92 \pm 0,22 \# \# \#$ \\
\hline ТГ, ммоль/л & $2,75 \pm 0,35 \# \#$ & $2,21 \pm 0,23 \# \# \#$ & $2,17 \pm 0,19^{\circ} \# \# \#$ \\
\hline ХС лПВГ, ммоль/л & $1,02 \pm 0,19 \# \#$ & $1,23 \pm 0,24 \# \#$ & $1,14 \pm 0,21^{\circ} \#$ \\
\hline ЗХС-ХС лПВГ & $5,72 \pm 0,28 \# \# \#$ & $3,61 \pm 0,32 * \# \#$ & $3,79 \pm 0,27^{\circ} \# \# \#$ \\
\hline ХС ЛПВГ & & & \\
\hline
\end{tabular}

Примітка. Достовірність різниці: між I та II групами $-{ }^{\circ} \mathrm{p}<0,05 ;{ }^{\circ 0} \mathrm{p}<0,05 ;{ }^{\circ 00} \mathrm{p}<0,05 ;$ між I та III групами -\#p $<0,05 ; \# \# p<0,01 ; \# \# \# p<0,001$.

Результати проведених досліджень засвідчили, що у жінок-курців (І група), порівняно з жінками, які не курили (II група), реєструють достовірно вищі проатерогенні фракції ліпідів до підвищення рівня: 3ХC - в 1,21 раза (відповідно $(6,86 \pm 0,34)$ ммоль/л (I) і $(5,67 \pm 0,29)$ ммоль/л (II), p<0,05), ХС ЛПНГ-в 1,27 раза $((4,39 \pm 0,27)$ ммоль/л (I) і $(3,46 \pm 0,38)$ ммоль/л (II), $\mathrm{p}<0,05)$, ХС лПДНГ-в 1,21 раза $((1,14 \pm 0,19)$ ммоль/л (I) і $(0,94 \pm 0,16)$ ммоль/л (II), p<0,05) і ТГ - в 1,24 раза

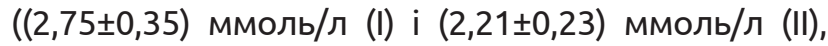
$\mathrm{p}<0,01)$. Водночас, вміст у крові ХС лПВГ в І групі був в 1,21 раза нижчим і становив, відповід-

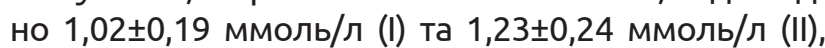
p<0,01). Як свідчать отримані нами дані (табл. 1), наявність в анамнезі куріння у пацієнтів з НС посилювало атерогенні порушення В ліпідному спектрі крові неоднаково, залежно від статі. Так, у жінок-курців спостерігали зростання вмісту в крові 3ХС в 1,29 раза, порівняно з чоловіками-курцями (відповідно $(6,86 \pm 0,34)$ ммоль/л (I) i $(5,47 \pm 0,25)($ III), $\mathrm{p}<0,05)$, ХС ЛПНГ - в 1,31 раза $((4,39 \pm 0,27)$ ммоль/л (I) і $(3,39 \pm 0,16)$ ммоль/л (III), $\mathrm{p}<0,05)$, ХС лПДНГ-в 1,23 раза $((1,14 \pm 0,19)$ ммоль/л (I) і $(0,92 \pm 0,22)$ ммоль/л (III), $\mathrm{p}<0,05)$ і ТГ- в 1,25 раза $((2,75 \pm 0,35)$ ммоль/л (I) і $(2,17 \pm 0,19)$ ммоль/л (III), $\mathrm{p}<0,05)$. Щодо вмісту у крові ХС ЛПВГ, то в І групі цей показник був в 1,17 раза нижчим, ніж в III групі (відповідно $(1,02 \pm 0,19)$ ммоль/л (I) та $(1,14 \pm 0,21)$ ммоль/л (III), $\mathrm{p}<0,05)$.

Отримані дані узгоджуються з даними інших авторів [15], які свідчать, що куріння і вторинний дим сприяють підвищенню вмісту ЗХС в крові. Як діагностичний і прогностичний предиктор гострих форм IXC розглядають співвідношення XC лПВГ до ХС ЛПНГ, яке у курців нижче, ніж у некурців. У тих, хто відмовився від куріння, вже протягом найближчих тижнів концентрація в крові XС ЛПВГ істотно підвищується [16].

Атерогенні зміни в ліпідному спектрі крові у пацієнтів-курців відбуваються в напрямку надходження ЗХС до судин, порівняно з його виведенням, про що свідчило суттєве зростання величини співвідношення ХС ЛПНГ/ХС ЛПВГ (на $30,4 \%$, p<0,001 у жінок-курців; на 26,7 \%, p<0,001 
Огляди літератури, оригінальні дослідження, погляд на проблему

у чоловіків-курців). Показник внеску ліпопротеїдліполізу ТГ-вмісних ЛПДНГ в утворення ЛПВГ (співвідношення ТГ/ХС ЛПВГ) у жінок-курців на $8 \%(p<0,05)$ знижений за рахунок зміни вмісту ЗХС у складі ЛПВГ $[17,18]$.

В наших дослідженнях активність ПОЛ визначалась за рівнем малонового діальдегіду. У жінок-курців цей показник був у 1,26 раза вищим, ніж у жінок-некурців $((0,72 \pm 0,14)$ ммоль/л (I) і $(0,57 \pm 0,12)$ ммоль/л (II), $p<0,05)$ та вищим у 1,13 раза, ніж у чоловіків-курців $((0,72 \pm 0,14)$ ммоль/л (I) і $(0,64 \pm 0,11)$ ммоль/л (III), p<0,05).

Спостерігалось підвищення вмісту церулоплазміну в 1,18 раза у пацієнтів III групи, порівняно з пацієнтами I та II груп, в яких рівень ЦП був практично однаковий (відповідно 406 $\pm 3,86$ ммоль/л (III) проти $380 \pm 2,17$ ммоль/л (I) і $378 \pm 3,12$ ммоль/л (II) (р<0,01)) (табл. 2).

Таблиця 2. Показники ПОЛ та рівня АОЗ у хворих на нестабільну стенокардію залежно від статі і звички куріння

\begin{tabular}{|l|c|c|c|}
\hline \multicolumn{1}{|c|}{ Показники } & $\begin{array}{c}\text { І група } \\
(\mathrm{n}=23)\end{array}$ & $\begin{array}{c}\text { II група } \\
(\mathrm{n}=24)\end{array}$ & $\begin{array}{c}\text { III група } \\
(\mathrm{n}=21)\end{array}$ \\
\hline МДА & $0,72 \pm 0,14 \# \#$ & $0,57 \pm 0,12^{\circ \circ} \# \# \#$ & $0,64 \pm 0,11^{\circ \circ} \# \# \#$ \\
\hline ЦП & $380 \pm 2,17 \# \#$ & $378 \pm 3,12^{\circ \circ} \# \# \#$ & $406 \pm 3,86^{\circ} \# \#$ \\
\hline
\end{tabular}

Примітка: достовірність різниці: між I та II групами - ${ }^{\circ} \mathrm{p}<0,05 ;{ }^{\circ} \mathrm{p}<0,05 ;$ між I та III - \#p<0,05; \#\#p<0,01.

Отримані результати (табл. 2) свідчать про те, що у чоловіків-курців краще, ніж у жінок-курців, активується антиоксидантний захист. Високий рівень маркера поглиблення прооксидантної ланки на фоні зниження антиоксидантного захисту у жінок-курців з НС свідчить про порушення балансу між цими складовими у бік надлишкового утворення ліпідних пероксидів та вільних радикалів, що призводять до поглиблення ендотеліальної дисфункції та пришвидшення розвитку атеросклеротичних змін у стінці артерії.

Висновки. Ужінок-курців, хворихна НС, спостерігаються істотні розлади ліпідного обміну атерогенного характеру, зокрема підвищення рівня $3 X \mathrm{C}$ і ХС ЛПНГ, гіпертригліцеридемія та зниження рівня ХСЛПВГ.Порівнянозжінками-некурцямитачоловіками-курцями, у жінок-курців спостерігаються най-

\section{ЛІТЕРАТУРА}

1. Зербіно Д. Д. Інфаркт міокарда у хворих молодого віку: предиктори і особливості перебігу / Д. Д. Зербіно, Т. М. Соломенчук, В. А. Скибчик // Укр. кардіологічний журнал. - 2004. - № 4. - С. 89-94.

2. Тютюнопаління: у пошуках виходу // Укр. мед. часопис. - 2015. - № 3(107), V(VI). - C. 63-64.

3. Dogan A. Acute effect of passive smoking on left ventricular sustolic and diastolic function in healthy volunteers / A. Dogan, M. Yarlioglues, I. Gul [et al.] // Journal of the American Society of Echocardiography. - 2011. Vol. 24 (2). - P. 185-191.

4. Бугаенко В. В. Гендерные особенности диагностики, течения и лечения ишемической болезни сердца / В. В. Бугаенко, И. П. Голикова, М. Ю. Шеремет // Рациональная фармакотерапия. - 2015. - № 1(34). - С. 5-20.

5. Towfighi A. Sex-specific trends in midlife coronary heart disease risk and prevalence / A. Towfighi, L. Zheng, B. Ovbiagele // Arch. Intern. Med. - 2009. - Vol. 169(19). P. $1726-1762$.

6. Волков В. И. Факторы риска сердечно-сосудистых заболеваний у женщин / В. И. Волков // Мистецтво лікування. - 2014. - № 2(108). - С. 24-27.

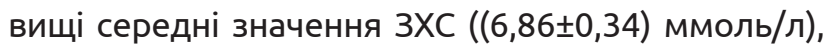
ХС ЛПНГ $((4,39 \pm 0,27)$ ммоль/л), ХС ЛПДНГ $((1,14 \pm 0,19)$ ммоль/л), ТГ $((2,75 \pm 0,35)$ ммоль/л), а також найнижчий середній рівень ХС ЛПВГ

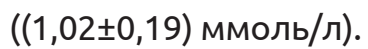

Найгірший стан ПОЛ встановлено у жіноккурців, хворих на НС, у яких рівень МДА виявився найвищим, а ЦП - найнижчим, що свідчить про значну активацію прооксидантних процесів на фоні виснаження антиоксидантного захисту.

Перспективи подальших досліджень полягають у детальному вивченні стану коронарних судин у курців та некурців, хворих на НС, шляхом проведення коронарографій, а також можливостей медикаментозного впливу на ліпідний обмін та систему пероксидації крові, зокрема препаратами Корвітин та Капікор.

7. Roger V. On Behalf of the American Heart Association Statistics Committee and Stroke Statistics Subcommittee Heart Disease and Stroke Statistics - 2011 update: a report from the American Heart Association / V. Roger, A. Go, Lloyd - Jones D. [et al.] // Circulation. - 2011. Vol. 123. - E. 18-109.

8. Hennekens C. H. Risk factors for coronary heart disease in women / C. H. Hennekens, M. D. Becker // Cardiol. Clin. - 1998. - Vol. 16 (1). - P. 1-8.

9. Grassi D. Oxidative stress and endothelial dysfunction: say NO to cigarette smoking / D. Grassi, G. Desideri, L. Ferri [et al.] // Department of internal Medicine and Public Health, Italy. - 2010. - № 16(23). - P. 2539-2550.

10. Лысенко М. Э. Функциональное состояние эндотелия и особенности липидного спектра крови при ишемической болезни сердца / М. Э. Лысенко // Укр.терапевтичний журнал. - 2006. - № 2. - С. 21-24.

11. Law M. R. Environmental tobacco smoke and ischemic heart disease / M. R. Law, N. J. Wald // Prog. Cardiovasc Dis. - 2003. - № 46 (1). - P. 318. Review.

12. Pechacek T. F. How acute and reversible are the cardiovascular risks of secondhand smoke? / 
Огляди літератури, оригінальні дослідження, погляд на проблему

T. F. Pechacek, S. Babb//BMJ.-2004. - №24, T.328(7446).P. 9803.

13. A strategy to prevent chronic disease in Europe. A focus on pub+ lic health action. The CINDI vision -WHO, 2004. $-41 \mathrm{p}$

14. Wang T. J. New cardiovascular risk factor exists, but are they clinically useful? / T. J. Wang // Eur. Heart J. 2008. - Vol. 29, № 4. - P. 441-444.

15. Yuan $H$. The effects of second-hand smoke on biological processes important in atherogenesis / $\mathrm{H}$. Yuan, L. S. Wang, M. Bhattacharya [et al.] // Graduate program. 2007. - № 8. - P. 1-7.
16. Tonstad S. Does shortterm smoking cessation reduce plasma total homocysteine concentrations? / S. Tonstad, P. Urdal // Scand J. Clin Lab Invest. - 2002. № 62 (4). - P. 279-284.

17. Правостатин в коррекции атерогенной экзогенно-индуцированной постпрандиальной гиперлипидемии / М. Г. Бубнова, Д. М. Аронов, Н.В.Перова [и др.] // Кардиология. - 2002. - № 1. - С. 27-32.

18. Batic-Mujanovic O. Influence of smoking on serum lipid and lipoproteins levels among family medicine patients / O. Batic-Mujanovic, A. Beganlic, N. Salihenfendic [et al.] // Med. Arch. - 2008. - Vol. 62. - № 5-6.- P. 264-267.

\section{ATHEROGENIC AND METABOLIC DISORDERS AND ASSESSMENT OF THE SYSTEM OF LIPID PEROXIDATION IN SMOKERS, PATIENTS WITH UNSTABLE ANGINA}

\section{()T. M. Solomenchuk, A. O. Bedzay}

Danylo Halytskyi Lviv National Medical University

SUMMARY. The study involved 68 patients with unstable angina (UA), of which 23 female smokers, 24 women who did not smoke and did not subjected to passive smoking exposure and 21 male smokers. In women smokers compared with women who did not smoke and male smokers there was observed growth rates of total cholesterol, hight-density lipoprotein (HDL), low-density lipoprotein (LDL) cholesterol lipoprotein very low density (VLDL), triglycerides (TG) and activity of lipid peroxidation and the content of HDL cholesterol was lower than in female non-smokers and women. The level of ceruloplasmin (CP) was higher in male smokers than female smokers and non-smokers, in which the level was almost the same CPU.

KEY WORDS: unstable angina, women smokers, women non-smokers, male smokers, lipid metabolism, lipid peroxidation. 